\title{
The Implementation of Balance Scorecard and Its Impact on Performance: Case of Universiti Utara Malaysia
}

\author{
Peter U. Anuforo \\ Tunku Puteri Intan Safinaz School of Accountancy \\ College of Business \\ Universiti Utara Malaysia, Malaysia \\ Email: peteru.love@gmail.com \\ Hazeline Ayoup \\ Tunku Puteri Intan Safinaz School of Accountancy \\ College of Business \\ Universiti Utara Malaysia, Malaysia \\ Email: hazel@uum.edu.my \\ Umar Aliyu Mustapha \\ Faculty of Economic and Management Sciences \\ Department of Accounting \\ Universiti Sultan Zainul Abidin (UniSZA), Malaysia \\ Email:umaraliyu2011@gmail.com \\ Ahmad Haruna Abubakar \\ Tunku Puteri Intan Safinaz School of Accountancy \\ College of Business \\ Universiti Utara Malaysia, Malaysia \\ Email: ahmadhabubakar@gmail.com
}

\begin{abstract}
The intensity of competition among contemporary Higher Education Institution (HEIs) has led to many of such institutions to focus more on how to provide high quality education so as to attain a suitable position in the university world ranking by adopting a suitable performance management. This study aims to demonstrate how UUM implement and uses the BSC to enhance and improve its strategic plans by addressing the issues facing its strategic management process. This study employed a qualitative case study approach. Data were collected using interview and reviewing the university quarterly and annual reports, organizational structure and the university's webpage as well as its news bulletins. Data were analyzed qualitatively using thematic analysis. Consistent with Kaplan and Norton BSC model in public sector, findings indicates that the case institution implements the BSC ideology by adapting the concept such that it reflects the unique contextual needs of UUM. This study found that in implementing the BSC project, the university staff's buy-in, top management commitment, organizational culture and communication strategy has significant effects on the case institution's performance. Also, findings revealed that the implementation of BSC ideology in UUM has a significant impact on its performance in that it helps in improving the case institution's overall university rankings. The implication of BSC implementation in UUM is that it helps the university management to monitor its performance with regard to its 2016-2020 phase II strategy plans. Future study should consider more institution that implements BSC so as to get more detail results that may be generalized.
\end{abstract}

Keywords: Balance Scorecard; Critical Success Factor; Performance Indicators; Performance Management; Performance Measurement; Universiti Utara Malaysia.

\section{Introduction}

Globalization forces such as competition in terms of university rankings in the educational sector have brought to bear incessant changes and challenges that have heavily affected the performance of both private and public institutions across the globe. As a result, educational institutions that plan to survive these dreaded issues and 
challenges have attempted to seek for suitable performance management such as Balance Scorecard (BSC). Thus, institutions that leave an indelible mark amidst counterpart globally, are those that effectively implements suitable strategic performance management model (Sharma, 2009). Moreover, studies have shown that performance management is crucial to the success and sustainability of institution of higher learning (Horngren, Datar, and Rajan, 2012). As such, in order to sustain and remain competitive in the university rankings and ratings, the institution of higher learning must ensure that its performance is up to the standards of world class university, which can be attained by adopting suitable strategic management tool such as the BSC. Hence, the motive of this study is to attain such goal by exploring how Universiti Utara Malaysia (UUM) implements its strategic plans to address its performance related issues.

Performance management system (PMS) is a vital element in managing an institution. Various PMS models have been developed by researchers and practitioners. Among all, the Balance Scorecard (BSC) is one of the most popular PMS that has been used worldwide by private as well as public institutions. This study is conducted to understand the BSC practices in a public institution in Malaysia. Specifically, this chapter discusses the background of the study. It consists of the following outlines that are the background of the study (i.e. introduction to BSC as both a performance and management tool), problem statement, research questions and research objectives, thereafter the scope and significant of the study and lastly chapter summary. This study aims to investigate and provide insight into how the BSC methodology is being implemented and its impact on performance.

One important criterion/yardstick for measuring and managing the success of institution of Higher learning is Performance (Gamal, and Soemantri, 2017). Studies have shown that the implementation of suitable performance management is one of the main concerns in the field of strategic management study. Performance management has been defined as the process of using performance measures to find out whether there is improvement in firm's performance (Zheng, Morrison, and O'Neill, 2006). Similarly, Bititci, Carrie, and McDevitt, (1997, p3) “defined performance management as a process that allows an organization to handle its performance in line with strategy and objectives". Also, according to Neely, Gregory, and Platts, (2005), performance management system has been regarded as a vital and indispensable organizational function. As such, a good performance management facilitates performance improvement. Thus, in recent years concerns for performance improvement has led to the introduction of various forms of strategic performance management and measurement systems such as the BSC by Kaplan and Norton (1996a), Performance Prism by Neely, Adams, and Kennerley (2002), Performance Pyramid by Lynch and abridge Cross (1991), Integrated Performance Measurement System by Bitichi et al. (1997), Consistent Performance Measurement System by Douwe Flapper, Fortuin, and Stoop (1996), Results and Determinants Matrix by Moon and Fitzgerald (1996), among others (Lee, 2006). The inadequacies of traditional performance measurement system have led to the development of BSC which incorporate financial and non-financial performance measures.

Within the context of BSC, performance management simply refers to the process of managing the drivers of performance (Bourne, Neely, Mills, and Platts, 2003). Note that the concept of BSC evolved from performance measurement to performance management which is used to strategically align financial and non-financial measures (Kaplan and Norton 1996b; Brudan, 2010; Witcher, and Chau, 2007; Huang, and Hu, 2007; Ayoup, Omar, and Rahman, 2016). Essentially, the BSC focuses on how to manage the measures that drives performance. Thus, the Cornerstone of BSC is how its balances or manages the 4 perspectives of performance measurement. The BSC has undergone series of modification and improvement since it was introduced.

The objective of this study is to examine the implementation of BSC and its impact on the performance of institutions of higher learning particularly in UUM (Universiti Utara Malaysia).Although, there is little or no specific documented studies addressing BSC implementation here in UUM. Hence, this study aims at employing the BSC model in evaluating both the financial and non-financial performance of the case institution. There are four perspectives of BSC but in this study, more emphasis is placed on the exceptional relevance of the non-financial performance measures within the context of the educational institution. The reason is that the university is essentially a service provider. However, looking at the dearth of previous studies, little has been done to emphasize on the exceptional relevance of the non-financial perspectives particularly in educational settings in contrast to a financial perspective which is considered to be more important (perspective among all the other perspectives of BSC) in the commercial business entity. Moreover, the reason for the choice of this unit of analysis in spite of other available high performing universities in Malaysia is because of its uniqueness as a non-comprehensive university that focuses on management related courses which have earned its international presence and attraction even beyond Asian countries.

\subsection{Research Questions}

- How does UUM implement the BSC?

- What are the impacts of BSC implementation on UUM's performance?

- What are the critical success factors (CSF) needed to improve UUM's non-financial performance? 


\subsection{Research Objectives}

The primary objective of this study is to explore the implementation of BSC in UUM. Specifically, the present study seeks to address the following research objectives:

- To explore the process of BSC implementation in UUM.

- To identify the extent of the impact of BSC implementation on UUM's performance.

- To investigate the critical success factors that drive UUM's non-financial performance.

\section{Background of Universiti Utara Malaysia (UUM)}

Universiti Utara Malaysia (UUM) was the sixth Malaysian public university which was formally established on $16^{\text {th }}$ February 1984 as the only university, that was mainly set up to solely specialize on management education. The university has the primary objective of training and producing the requisite pool of professionals, especially in the field of business and management for both the international markets and the local inclusive. The university also believes in the philosophy that institutions should be universally recognized, and supports the view that knowledge goes beyond national boundaries.

As another way of championing and promoting the name and the agenda of UUM in the histories of its academic excellence, of being an Eminent Management University as well as a research base university that focuses in Social Sciences, hence the Vice-Chancellor of UUM, Prof. Dato' Dr. Mohamed Mustafa Ishak, in conjunction with the laid down 2011 strategic plan launched a Transformation Plan. Moreover, UUM Transformational Plan, which is mainly a roadmap showing the future endeavors and pursuits of UUM, is categorized into two phases. The 2011-2015 strategic plans - Phase I, focused exclusively on placing UUM on the local academic map in a strategic and systematic way while the Second Phase of the university strategic plan which is a continuation of the Phase I Strategic Plan was basically meant to run from 2016-2020.

UUM have not been proactively adopting BSC per say, but the ideology with the view of addressing the quantum of issues and challenges confronting its strategic management process. UUM is one of the Malaysian public universities that enroll a significant number of international students from various parts of the country. The university has attracted a significant number of international students when compared to its counterparts, reasons being that the university does not make its indigenous language course compulsory for postgraduate students in contrast to its counterparts. More recently, the university performance has enabled it to attain AASCB university ranking accreditation which has prompted the need to adopt a suitable performance that will help to sustain and increase its performance. In spite of the above performance of the university and recognition beyond national to international presence, the university is confronted with a series of issues ranging from performance management, how to sustain and improve its performance as well as its general rankings both within and across the country. Consequently, it also attempts to accomplish both its short and long term objectives as enshrined in its vision and mission.

In sum, as mentioned earlier, the selection of appropriate performance management nowadays is very vital to the institution of higher learning because at the end of the day the outcome of the performance of such institution will determine the ranking profile of the university among its competing counterparts. For example, recently, there was a policy that was issued by the gov't of one of the African countries regarding its student's enrolment in the Malaysian university. Five best Malaysian public universities were selected in this policy; hence this will obviously affect the number of student's enrolment in any of the university that fails to meet this criterion of "five best Malaysian public universities". Thus, the choice of appropriate performance management such as BSC and the strategic implementation process is fundamental to the success and improvement of the ranking profile of contemporary institutions of higher learning especially among the public Malaysian universities.

\section{Literature Review}

\subsection{Balance Scorecard}

This study is replete with past studies on BSC implementation and its impact on organization's performance (e.g. Kaplan and Norton 1992; Crabtree and DeBusk, 2008; Davis and Albright, 2004: Lubis, Torong, and Muda, 2016; Martello, Watson, and Fischer, 2016; de la Mano, and Creaser, 2016; Calderon Molina, Palacios Florencio, Hurtado Gonzalez, and Galan Gonzalez, 2016; Hu, Leopold-Wildburger, and Strohhecker, 2017; Gamal, and Soemantri, 2017; Singh, and Arora, 2018; Osewe, Gachunga, Senaji, and Odhiambo, 2018).

According to Zolfani and Ghadikolaei (2013) the theory of Balanced Scorecard (BSC) was propounded by "David Norton, the CEO of Nolan Norton Institute, and Robert Kaplan, a professor at Harvard University" (Kaplan, Norton 1992). The BSC is presently one of the most valued contemporary performance management that is widely adopted as a performance management system which improves financial and non-financial performance (Norreklit, 2003; Wong-On-Wing, Guo, Li, and Yang, 2007; Witcher and Chau, 2007; Modell, 2012; Ayoup, Omar, and Rahman, 2015a). The BSC has been widely adopted and rated by both academics and practitioners as the most popularly used and suitable performance management model. Zin, Sulaiman, Ramli, and Nawawi, (2012), stressed that the BSC has 
been generally claimed as the most popular tool of performance management, used by the academicians and the practitioners as a result of its comprehensive and holistic approach towards enabling institutions to identify its core vision, mission, strategic objectives, and targets respectively. For example, studies have shown that the BSC is an advance model for organization's strategic orientation adopted by over 54\% of the total 1230 global firms (Rigby, and Bilodeau, 2011; Elola, Tejedor, Pastor Tejedor, 2016; Gamal, and Soemantri, 2017). However, the inception of the BSC since 1992 as an influential strategic management tool till date, have constituted a subject of debates both among the academia and the practitioners (Ayoup, et al., 2015a). Thus, the BSC has suffered a lot of criticism and setback from both academia and practitioner, especially in terms of its implementation process. For example, in spite of its popularity, studies have indicated that about $70 \%$ of BSC project have failed in organizations, due to half hazard implementation and lack of understanding how to implement and execute the framework and other related issues such as employees buy-in, managers' acceptance, misalignment of organizations strategies inadequate support and buy-in from top management (and/or) at all levels of management etc. (Neely and Bourne, 2000; Tarigan 2005; Kaplan and Norton 1992, 1996a, 2001, 2004 and 2006a; Modell, 2012; Ayoup, Omar, and Rahman, 2012; Ayoup, Omar, and Rahman, 2016; Ayoup, et al., 2015a). Danesh Asgari, Haeri, and Jafari, (2017,p1), also stressed that "the momentous issue, in BSC implementation, is essentially based on the proper selection of measures".

Despite the aforementioned limitations and challenges of BSC project, studies have revealed that, to some certain extent, the BSC have benefitted organizations that have implemented it especially in the private sector, although most of the success stories are not being properly documented or shared openly to outsiders. Examples, of such successful companies include; Tata Motors, IBM, HSBC Rail, Ricoh, Thorton Oil, DuPont, Tokyo, Mitshubishi HQA and Bank of Tokyo, Infosys Technologies, AT and T Canada etc. Similar examples are also found in the educational sector particularly in institutions of higher learning. Thus, BSC practice in the institution of higher learning across the world, particularly in the UK, USA, Canada and Australia have successfully implemented BSC with a view of building strong international brands and ultimately maintaining a top global ranking consistently. Similarly, Vermaak, and Cronje, (2001), perceived the BSC as a strategic management tool for strategic planning and also as a performance improvement used in South African and Australian universities. Additional success story found in institution of higher learning includes; "the University of Edinburgh, Ohio State University, University of Southern California, University of Akron, University of California, and so on (Walker and Ainsworth 2007; Balanced Scorecard Institute 1998-2008; Karathanos and Karathanos 2005; Umashankar and Dutta 2007)". Also, for any institution of higher learning to successfully achieve a well-recognized high ranking profile in the university world rankings, it becomes essentially necessary for such institution to adopt a suitable performance management tool such as the BSC.

One of the main contributions of successful BSC implementation as outlined by many studies is its ability to develop critical success factors that align and promote strategic performance management geared towards attaining the institution's vision, mission and strategies (Kaplan and Norton, 1996, 2000, 2004, 2006b; Ayoup, 2009). Although, despite the benefits arising from BSC implementation, up until now, there is little or lack of published studies on BSC implementation process in institutions of higher learning, especially in Asian countries such as Malaysia (Othman, Domil, Senik, Abdullah, and Hamzah, 2006; Othman, 2008; Jusoh, and Parnell, 2008, Sandhu, Baxter, and Emsley, 2008; Ayoup, 2009). Moreover, the available studies are mostly undertaken in the western institution, which obviously has its own peculiar cultural related settings issues when compared to Malaysia (Davis, 1996; Maiga and Jacobs 2003; Davis and Albright 2004; Hendricks, Menor, Wiedman, and Richardson, 2004; Braam and Nijssen 2004; Ax and Bjornenak 2005; Decoene and Bruggeman 2006; Nielsen and Nielsen 2008; Ayoup, 2009). Thus, these, among other reasons are the motivations behind the current study which seeks to examine BSC implementation specifically in UUM.

3.2 BSC Implementation Issues

BSC implementation issues basically stem from the causal linkage of organization vision and strategy that is embedded in the four perspectives of the BSC and how the strategies in each perspective are integrated. The BSC suffers from several implementation issues despite the claim that it is the most regarded contemporary strategic management accounting tools that helps in improving organization performance (Kaplan and Norton 1992, 1996a, 2001, 2004 and 2006a; Modell, 2012; Ayoup, et al., 2016). The key issues underlining BSC implementation includes;

- Strategy misalignment

- Strategy communication issues

- The challenges of manager's acceptance/employees buy-in

- The issue of clarity of vision, mission, strategy, and outcome

- Strategy map implementation issues 


\subsection{The Critical Success Factors of BSC Implementation}

Papenhausen and Einstein (2006) studies on BSC implementation in a college of business found that the implementation of a strategy requires the buy-in of everyone in the institution to participate actively especially in the daily operations of the business. Thus, communication and staff education as well as commitment play a vital role in actualizing institution's initiatives. According to Farid, Nejati, and Mirfakhredini (2008) in order to create a causal relationship, all staff needs to work together. Thus, Ahmad and Soon (2015) stress that communication plays a significant role in the effective BSC implementation because it is regarded as one of the main critical success factors of the BSC implementation project. Thus, effective communication helps to minimize the issue of resistance to change by employees and promotes good momentum during the phase of the implementation process.

Furthermore, Ayoup et al. (2012), using the case study approach highlighted that their studies support other research, as such communication may constitute one of the factors that impede manager's understanding of the BSC as a performance management system employed in the organization in addition to understanding the strategy alignment between BSC measures, the company's goals, and targets, KPIs and the institution's reward system. Moreover, the study also concludes by stating that communication plays a vital role in the implementation process of BSC, as supported similar studies (Kaplan and Norton, 2001; Hendricks, Menor, Wiedman, and Richardson, 2004; and Pandey, 2005).

According to Chen, Yang, and Shiau, (2006), the implementation of BSC in an institution of higher learning requires faculty staff to exercise team spirit in their work. And this usually starts with senior staffs that are responsible for implementing policies in a hierarchy of top-to-bottom.

In sum, significant studies have identified the critical success factors (CSF) of BSC to include top management support, communication, information technology, organizational culture and employee's buy-in (Singh, and Arora, 2018; Ferreira, 2017 and Zin, et al., 2012; Kaplan and Norton 2004; Dimitropoulos, Kosmas, and Douvis, 2017; Slavica, Ljubica, and Jelena, 2017; Ayoup, et al., 2016; Othman, et al., 2008). Moreover, the strength of BSC lies in its ability to develop a system of evaluation that generates suitable performance indicators in educational institutions. Additionally, according to Kaplan, and Haenlein (2010) BSC can only be used properly when its performance measures are aligned with the overall strategy of an organization

\subsection{BSC Implementation in Institution of Higher Learning (HEI)}

The dearth of published research on BSC shows that, the BSC concept has not been widely embraced by the educational institution unlike the business sector where there is extensive evidence of BSC adoption (Karathanos and Karathanos, 2005). The prior purpose of developing the BSC was initially meant for the profit oriented outfit with the aim of enhancing financial success, however it was later adopted by, and adapted in public sector outfit as an arrangement geared towards providing and communicating effective service to the public. Kaplan and Norton (1999) stressed that the BSC is not just applicable to the public sector organization, but also very suitable. However, it is important to reiterate here that the BSC provides better prospects and potentials of enhancing management performance in not-for profit organization and tend to be more promising in yielding better results (Kaplan and Norton 1999: 1). Hence, the framework of the BSC application in the public sector needs to be adjusted in order to reflect its peculiarity and the uniqueness of its mission driven nature since it focuses more on promoting accountability and results in satisfying user expectations for public services.

Essentially, the institution of higher learning (HEI) is known to be solely a service provider. Thus, the university performance system is a multifaceted social system which requires a holistic approach. Al-Zwyalif (2012), argued that the educational institution focus on organizational performance is influenced by the rapid change of global environment and technology. Thus, this assertion was further supported by Binden, Mziu, and Suhaimi, (2014) in which they found that the implementation of performance management system has become a trend in educational institutions. However, in order to measure institutions performance, Al-Zwyalif (2012), stressed that educational institution should implement the BSC in such a way that it will enable it to evaluate and manage the overall performance. Although, (Gmelch, and Wolverton, 2002) highlighted that the university world today, is confronted with complex and tasking competitive reality. Similarly, Barlas, and Diker, (2000) indicate that modern-day universities worldwide are confronted with management difficulties such as uneven growth in the number of students population in the universities, inadequate infrastructures that may not cater for the increase in students enrolment, increased number of student to faculty ratios, concern about quality of teaching, pronounced competition for insufficient funding for research, and aggressive competition by private universities for more student demand. Moreover, these issues are interrelated and interact closely and simultaneously, hence contributing more complexity in the dynamic set up of the universities performance system. More so, according to Taylor and Baines (2012) Universities are now facing intense competition in terms of student enrolment thereby, prompting further consideration of the entire student experience. Moreover, international student enrolment is especially more pronounced; hence, the institution of higher learning is increasingly looking for new forms of internal management. 
Beard (2009) found out that identifying and adopting vital performance measures that are consistent with the university's core values and mission and ensuring continuous improvement provides opportunities of creating educational value in the institution of higher education. She added that, the process of developing and implementing the BSC offers the opportunity of identifying stakeholders and customer's value, the mission and vision, as well as the objective of the institution. According to Zangoueinezhad and Moshabaki (2011), the model of BSC is regarded as one of the most suitable and appropriate strategic performance management used in managing the higher education institutions compared to other strategic performance management tools. Thus, the BSC can be applied in the educational institutions to strengthen the significance of managing instead of only monitoring performance (Cullen, et al., 2003). Furthermore, Nambi and Werner (2013) conducted a study on "determining the challenges influencing the implementation of performance measurement in Uganda public universities" in which they found out that, the absence of a formal performance management setting constituted the major issues confronting the universities which hinders effective performance measure implementation.

One of the difficulty of implementing the BSC model is the need to modify the concept to reflect the peculiarity of the organization in question especially in terms of the institution's mission, vision, strategy, technology and culture; otherwise the intended result or benefit may not be achieved (Kim, Suh, and Hwang, 2003; Khomba, Vermaak, and Hanif, 2012; Chimtengo, Mkandawire, and Hanif, 2017). Although, some scholars suggested that the BSC may likely not be appropriate for the educational institution and may only be suitable for profit-oriented organizations. On the contrary, the scorecard can be modified to address the specific needs of the academic organization. For example, "the Rossier School of Education at the University of Southern California adopted the BSC to measure the effectiveness of its academic program (Sutherland 2000 cited by Umashankar and Dutta 2007)". Additionally, the examples of other universities across the globe, that have implemented the BSC with obvious significant performance improvement includes; "the University of Southern California, University of Edinburgh, Ohio State University, University of Akron, University of California, and so on (Balanced Scorecard Institute 1998-2008; Karathanos and Karathanos 2005; Walker and Ainsworth 2007; Umashankar and Dutta 2007)".

Beard (2009) argued that despite the fact that lack of awareness and understanding of how the BSC may be implemented in educational institutions being an aspect of strategic management, especially in terms of instructional functions, does not suggest that it may not be applicable. However, she highlighted the results of BSC implementation successes at the "at the University of Wisconsin-Stout, being the first university to receive the award in 2001 and Kenneth Monfort College of Business at Northern Colorado, a 2004 Malcolm Baldrige National Quality Award recipient. Although their respective individual measures vary significantly in various areas, by reflecting the differences in their individual vision, missions, and core values. For example, "Sutherland 2000 cited by Umashankar and Dutta 2007, presented that the Rossier School of Education at the University of Southern California implemented the BSC project aimed at to evaluating the program and planning process of its academic. Binde et al. (2014), in their studies having reviewed a significant number of articles on BSC implementation particularly as regards to measuring the performance of institution of higher learning found that a good number of educational institutions world-wide have recorded successes in BSC implementation process especially in terms of linking the four perspectives with the institution's missions, goals and policies.

\section{Research Methodology}

This study employed a qualitative case study approach because it is considered well-suited in answering the research questions appropriately and adequately, as well as its flexibility when compared to the design used in quantitative research design. The strength of the case study method lies in its ability to allow an in-depth examination of the phenomenon by using various kinds of evidence obtained from interviews with those involved, and analysis of documents and artefacts (Yin, 2003). Also, the case study was used because the focus of the study is more of description and explanation rather than prediction, and the variable studied is not easily unidentifiable or embedded in the phenomenon to be extracted for study (Merriam, 1988). Additionally, the case study allows for empirical inquiry of phenomenon in its real-life context; particularly when the boundaries between context and phenomenon are not evidently clear (Yin, 2003). More so, according to Creswell (2007) case study enables researchers to examine phenomena holistically within the context of real life situation. Adams, Hoque, and Mcnicholas (2006), corroborated this view by stressing that the case study approach entails eliciting information from practitioners' experiences and perception about the case institution as well as its management process. Moreover, the present study attempts to demonstrate how UUM Adapts the BSC to tackle the issues underlining its strategic implementation process tagged as "phase I and phase II strategy plan". UUM has been selected as the case institution since it has been adopting the ideology of BSC to implement its strategic plans, tagged as "strategy plans phase I (2011-2015) and phase II (2016-2020)" respectively.

Data was collected from both primary and secondary sources. Primary data collection sources involved using a semi-structured interview question via tape-recorder, and the key informants were mainly the Head of Department 
of the case institution. While secondary data was collected (through documentation) by reviewing the university quarterly and annual reports, organizational structure and the university's webpage and news bulletins. According to Creswell, (2007) and Yin, (1998), these approaches can lessen the possibility of the element human biases in providing information in contrast to just the interview and questionnaire survey.

Data were analyzed qualitatively using thematic analysis. The findings from the interview were itemized in a thematic report and narrative format in such a way that it will reflect the objective of the study in answering the research questions (Yin, 2003). Thus, all interviews were transcribed and transmitted into Microsoft Word 2010 files. To make sense of the transcribed data, it was analyzed into several themes based on the objectives of the study (Miles and Huberman 1994).

\section{Discussion of Findings}

The objective of this study is to explore and provide insight into how BSC is implemented and its impact on UUM's performance. The findings of this study are presented based on the objectives of this paper. Thus, this section discusses the findings with regards to BSC project and relevant extant literature as it relates to the case institution in this study. However, it is quite difficult to relate the results of this study to prior literature because the case institution actually adapted the ideology of the conventional BSC implementation process rather than adopting the model of BSC as originated by Kaplan and Norton.

\subsection{BSC Implementation Process}

According to Informant A, the BSC is a measurement tool. And the Key Performance Indicator (KPI) is the items that are used to translate how to manage performance within the context of BSC.

Consequent upon the usefulness of the BSC, UUM adapted this management tool, and modified it suitably within the context of the university. The university kind of BSC implementation is the implementation of KPIs which is a resemblance of the BSC and comprise of all the strategies and perspectives of the conventional BSC as originated by Kaplan and Norton. These KPIs is what the university refers to as the Strategic Plan (or Transformational Plan). Specifically, UUM BSC implementation process is otherwise known as Strategic Plans implementation which involves the implementation of the university's 4 thrust, 6 Key result areas, 12 Strategies, 7 Objectives, and 16 KPIs as well as other performance indicators (PIs) which are peculiar to other functions of the university (see appendix A for details). For example, there are 26 PIs that are related to the academic Staff.

UUM has managed to successfully attain 60 percent of the KPI listed in Phase 1 of the strategic plan. The Phase II Strategic Plan comprises of 4 thrust of the strategic plan unlike phase I that have 5 thrust of strategic plans. Essentially, Phase II of the Strategic Plan focuses mainly on UUM's international agenda, which encompasses QS (Quacquarelli Symonds) Ranking, QS Rating, US News Ranking, UI Green Metric, Webometrics, and Times Higher Education (THE).

5.2 Informant Experience in KPI Implementation Process from the 2010-till date (i.e. the Processes involved in Implementing BSC in UUM)

The Institute of Quality Management (IPQ) is a department that is responsible for planning, strategizing, implementing and monitoring of all quality related activities including continual Quality Improvement (CQI). It is tagged as "IPQ drives UUM endless potentials" and the IPQ department also focuses on driving the development of the university $3 \mathrm{E}$ governance system (centered on being Efficient, Effective, and Excellent) as well as striving for the realization of the university's strategic plan, especially with regard to its rankings and rating agenda.

Interview findings revealed that, in 2012, during the course of the implementation of the Strategic Plan, the university introduced a performance evaluation system called Strategic Planning Information System which was meant to support its Strategic Plan agenda. The system is essentially being used to monitor every single KPI performance. The system enabled the university to generate reports easily and accordingly. Moreover, this Strategic Planning Information System is actually similar to the conventional BSC especially in terms of monitoring the performance of the institution. Additionally, findings from interview indicate that, starting from 2013 onward, the performance reports were exclusively based on the various schools in the university. Thus, the reported achievements of the university were based on individual respective school performances.

The objectives of UUM Strategic Plan Phase II: 2016-2020 includes

- To provide cutting edge research, consultation and publication

- To establish effective teaching and learning

- To produce highly capable talent and human capital

- To develop reputable academic programs

- To provide state of the art infrastructure

- To produce holistic, entrepreneurial and balance student development

- And to establish effective and efficient financial management 
Analysis of the objectives of UUM Strategic Plan for both Phase I and II shows that UUM incorporates all the themes that are involved in all the 4 perspectives of BSC, except that it is within the context of the university. Moreover, phase II of the Strategic Plan focuses mainly on "UUM's international agenda, which encompasses QS (Quacquarelli Symonds) Ranking, QS Rating, US News Ranking, UI GreenMetric, Webometrics, and Times Higher Education (THE)". This is in addition to the national agenda, which involves RU, National Higher Educational Blueprint (NHEBP), SETARA and the university's specific agenda.

\subsection{The Impact of UUM KPIs on its Performance}

The results of the impact of the implemented Strategic Plan of Phase I (2011-2015) and Phase II (2016-2020) in UUM includes among others the following;

One of the informants, expressed an optimistic view regarding the concept of BSC and its associated positive impacts, according to him, the BSC is one of the best modern performance management tools that we have today, even though organizations have to adapt this BSC with some modification so as to reflect the institution's context. Similarly, articles on BSC have corroborated this view by stating that the BSC is one of the most influential contemporary performance management and measurement concept that ties and aligns both short-term strategic actions and long-term strategic goals of institutions even though the difficulty encountered is how to modify the BSC model to reflect the institution's mission, vision, strategy, technology and culture (Marr and Schiuma, 2003; Kim, et al., 2003; Khomba, et al., 2012; Chimtengo, et al., 2017; Anjomshoae, Hassan, Kunz, Wong, and de Leeuw, 2017).

One of the significant achievement of UUM's list of Phase I KPIs is that $65 \%$ of the 170 KPIs' was attained, thereby surpassing the intended target. Also, recently, UUM was found to be the only non-comprehensive and non-research university that was in the 2.7 per cent of universities list in the Quacquarelli Symonds, World University Ranking (QSWUR) 2018 out of 26,000 universities in the world. Additionally, the university had recorded a successful AACSB (Association of Advanced Collegiate School of Business) accreditation.

More so, a recent report by QSWUR, which is an annual ranking list of the best universities in the world, also revealed that "without having the fields of science, medicine, engineering and technology - and is only based on the social sciences and management, UUM succeeded in improving its ranking to 729 in QSWUR 2018, which is a jump of 10 spots compared to the previous year at 739, and is now ranked in the 701-750 bracket,". Also a total of nine Malaysian universities were listed in the most recent QS ranking issued on June 82017 in which UUM emerged $6^{\text {th }}$ and was also ranked among the 1,000 best universities in the world.

In terms of individual school achievements, one of the informants reported that the school of accountancy emerged as the best in Asia and the reasons was because of the significant number of its academy staff as PhD holder and other related vital advantages. In sum, the implementation of this Strategic Plans has ultimately increased and improved the overall performance of UUM based on the aforementioned outcomes of the impact of KPI implementation in the university.

(Appendix B, depicts UUM' recent ranking profile).

\subsection{The Critical Success Factors of BSC implementation process in UUM}

The university Critical Success Factors (CSFs) is the various yardsticks or Performance Indicators (PIs) put in place to monitor and measure the performance of the various schools, colleges, departments and so on, in order to checkmate their performance for a particular period of time.

Informant A reported that the most critical success factor is getting the "buy-in" from the various colleges, schools, deans, lecturers, academic staff, and the support staff.

Moreover, the critical success factors (CSF) that contribute to the successful implementation of BSC in the case institution was found to be similar with case evidence in Geomotion (Zin, et al. 2012). The evidence revealed that four critical success factors were necessary for BSC implementation to succeed. These factors include; top management commitment, communication, information technology, and organizational culture. Additionally, Singh, and Arora, (2018) supported this view by highlighting that top management support, interdepartmental communication and a good corporate culture serves an antecedent to BSC adoption which plays a significant role in ensuring that BSC implementation succeeds. They concluded by stating that the perception of management cannot be achievable without an adequate support from the top management, in addition to having a hitch free medium of communication in the organization.

The dearth of various studies and the data collected from participants interviewed in this study has revealed that one of the major CSF of implementing a successful BSC (or Strategic Plans as in this case study), is getting the buy-in of the employees or the management involvement via the efficient and effective communication system (Kaplan and Norton 2004; Dimitropoulos, et al., 2017; Slavica et al., 2017; Ayoup, et al., 2016).Similarly, management commitment has also shown to be of paramount importance in implementing a successful BSC. For example, as part 
of UUM's commitment to CQI (Continual Quality Improvement), all relevant policies and procedures are reviewed at least once a year at the University Quality Council (UQC) meeting, and improved upon where necessary.

And at the same time there is what the university call developing the Strategic Plan Information System. This system of technology is what the university used to monitor and communicate its strategic plans, which are much better than the one that was used manually before.

Interview result also shows that the case institution's organizational culture is quite a very complex concept. Similarly, the university is very much interested in a high performance culture, unlike before which is business as usual; the strategic plan to a certain extent shapes the university culture to become a high performance culture.

\section{Conclusion}

The research paper aimed at exploring and providing insight into how BSC is implemented and its impact on UUM's performance. This study employed a qualitative case study approach. Data were collected using interview and reviewing the university quarterly and annual reports, organizational structure and the university's webpage as well as its news bulletins. Data were analyzed qualitatively using thematic analysis. This study has revealed some tacit fascinating findings that boarder on the impact of UUM's BSC implementation methodology on its performance. Firstly, consistent with Kaplan and Norton BSC model, findings indicate that the case institution implements the BSC ideology and not the holistic and comprehensive BSC project, by adapting the concept such that it will reflect the unique contextual needs of UUM. Secondly, the study has shown that the implementation of BSC ideology in UUM has a significant impact on its performance in that it helps in improving the case institution's overall university ranking both national and international arena. Also, findings of this study show that the university staff's buy-in or involvement and commitment, as well as communication strategy has significant effects on the case institution's performance. Furthermore, this study was consistent with the findings of Zin, et al. (2012) that identified four critical success factors (top management commitment, communication, information technology, and organizational culture) which they consider as pivotal (i.e. CSF) to successful BSC implementation. Likewise, Singh, and Arora, (2018) findings supported the present study' findings in that they highlighted that top management support, interdepartmental communication and a good corporate culture plays a significant role in ensuring that BSC implementation succeeds.

\section{Implications}

With regards to the impact of BSC implementation on the performance of the case institution, it enables the management of the university to ascertain both its present and future performance so as to know how to monitor, improve and sustain its position in the university world ranking.

Overall, the finding of this study is particularly of great interest to both management scholars and practitioners such as university management, academia, non-profit outfit and governmental organizations (NPGOs), and so on.

\section{Recommendation for Future Study and Limitation of the Research}

Future studies may explore more number of institutions that implement BSC so as to enrich the findings such that the results may be generalized.

This study suffers from the limitations that are associated with the case study methodology because data collected and the results of this study are exclusively based on the case institution, hence results may not be generalized due to the fact that other institutions may have their own peculiar BSC implementation processes and management practices as well as challenges. Although, the findings still have value and may serve as a basis of reference to institutions that wants to implement BSC so as to improve their performance, especially institutions that share similar features like the case institution.

\section{References}

Adams, C., Hoque, Z., \& Mcnicholas, P. (2006). Case Studies and Action Research. Methodological Issues in Accounting Research: Theories and Methods, 361-373.

Ahmad, A. R., \& Soon, N. K. (2015). Balanced Scorecard in Higher Education Institutions: What Should be Consider?. In Technology Management and Emerging Technologies (ISTMET), 2015 International Symposium on (Pp. 64-68). IEEE.

Al-Zwyalif, I. M. (2012). The Possibility of Implementing Balanced Scorecard in Jordanian Private Universities. International Business Research, 5(11), 113.

Anjomshoae, A., Hassan, A., Kunz, N., Wong, K. Y., \& de Leeuw, S. (2017). Toward a dynamic balanced scorecard model for humanitarian relief organizations' performance management. Journal of Humanitarian Logistics and Supply Chain Management, 7(2), 194-218.

Ax, C., \& Bjørnenak, T. (2005). Bundling and Diffusion of Management Accounting Innovations-The Case of the Balanced Scorecard in Sweden. Management Accounting Research, 16(1), 1-20.

Ayoup, H. (2009). Observational Assessment of the Balanced Scorecard Strategic Alignment Process: A Study of a Utility Company. 
Ayoup, H., Omar, N. H., \& Rahman, I. K. A. (2012). Implementation of Balance Scorecard (BSC) in a Malaysian GLC: Perceptions of Middle Managers. Asia-Pasific Management Accounting Journal, 7(2), 99-123.

Ayoup, H., Omar, N., \& Rahman, I. K. A. (2015a). Behavioural Factors Affecting Strategic Alignment Based on the Balanced Scorecard Framework: Evidence From a Malaysian Company.

Ayoup, H., Omar, N., \& Rahman, I. K. A. (2016). Balanced Scorecard and Strategic Alignment: A Malaysian Case. International Journal of Economics And Financial Issues, 6(4S).

Barlas, Y., \& Diker, V. G. (2000). A Dynamic Simulation Game (UNIGAME) for Strategic University Management. Simulation \& Gaming, 31(3), 331-358.

Beard, D. F. (2009). Successful Applications of the Balanced Scorecard in Higher Education. Journal of Education for Business, 84(5), 275-282.

Binden, W., Mziu, H., \& Suhaimi, M. A. (2014). Employing the Balanced Scorecard (BSC) to Measure Performance in Higher Education-Malaysia. International Journal of Information and Communication Technology Research, 4(1).

Bititci, U. S., Carrie, A. S., \& Mcdevitt, L. (1997). Integrated Performance Measurement Systems: A Development Guide. International Journal of Operations and Production Management, 17(5), 522-534.

Bourne, M., Neely, A., Mills, J., \& Platts, K. (2003). Implementing Performance Measurement Systems: A Literature Review. International Journal of Business Performance Management, 5(1), 1-24.

Braam, G. J., \& Nijssen, E. J. (2004). Performance Effects of Using the Balanced Scorecard: A Note on the Dutch Experience. Long Range Planning, 37(4), 335-349.

Brudan, A. (2010). Rediscovering Performance Management: Systems, Learning and Integration. Measuring Business Excellence, 14(1), 109-123.

Calderon Molina, M. A., Palacios Florencio, B., Hurtado Gonzalez, J. M., \& Galan Gonzalez, J. L. (2016). Implementing the balanced scorecard: its effect on the job environment. Total Quality Management \& Business Excellence, 27(1-2), 81-96.

Chen, S. H., Yang, C. C., \& Shiau, J. Y. (2006). The Application of Balanced Scorecard in the Performance Evaluation of Higher Education. The TQM Magazine, 18(2), 190-205.

Chimtengo, S., Mkandawire, K., \& Hanif, R. (2017). An evaluation of performance using the balanced scorecard model for the University of Malawi's Polytechnic. African Journal of Business Management, 11(4), 84.

Crabtree, A. D., \& Debusk, G. K. (2008). The Effects of Adopting the Balanced Scorecard on Shareholder Returns. Advances in Accounting, 24(1), 8-15.

Creswell, J. W. (2007). Five qualitative approaches to inquiry. Qualitative inquiry and research design: Choosing among five approaches, 2, 53-80.

Cullen, J., Joyce, J., Hassall, T., \& Broadbent, M. (2003). Quality in Higher Education: from Monitoring to Management. Quality Assurance in Education, 11(1), 5-14.

Danesh Asgari, S., Haeri, A., \& Jafari, M. (2017). Integration of Balanced Scorecard and Three-Stage Data Envelopment Analysis Approaches. Iranian Journal of Management Studies, 10(2), 527-550.

Davis, S., \& Albright, T. (2004). An Investigation of the Effect of Balanced Scorecard Implementation on Financial Performance. Management Accounting Research, 15(2), 135-153.

Davis, S., \& Albright, T. (2004). An Investigation of the Effect of Balanced Scorecard Implementation on Financial Performance. Management Accounting Research, 15(2), 135-153.

Davis, T. R. (1996). Developing an Employee Balanced Scorecard: Linking Frontline Performance to Corporate Objectives. Management Decision, 34(4), 14-18.

De La Mano, M., \& Creaser, C. (2016). The Impact of the Balanced Scorecard in Libraries: From Performance Measurement to Strategic Management. Journal of Librarianship and Information Science, 48(2), 191-208.

Decoene, V., \& Bruggeman, W. (2006). Strategic Alignment and Middle-Level Managers' Motivation in a Balanced Scorecard Setting. International Journal of Operations and Production Management, 26(4), 429-448.

Dimitropoulos, P., Kosmas, I., \& Douvis, I. (2017). Implementing the Balanced Scorecard in a Local Government Sport Organization: Evidence from Greece. International Journal of Productivity and Performance Management, 66(3), 362-379.

Douwe P. Flapper, S., Fortuin, L., \& Stoop, P. P. (1996). Towards Consistent Performance Management Systems. International Journal of Operations and Production Management, 16(7), 27-37.

Elola, L. N., Tejedor, J. P., \& Tejedor, A. C. P. (2016). Analysis of the causal relationships in the balanced scorecard in public and private Spanish Universities through structural equation modelling. The Business \& Management Review, 7(5), 18. 
Farid, D., Nejati, M., \& Mirfakhredini, H. (2008). Balanced Scorecard Application in Universities and Higher Education Institutes: Implementation Guide in an Iranian Context. Universitatii Bucuresti. Analele. Seria Stiinte Economice Si Administrative, 2, 29.

Ferreira, A. M. S. C. (2017). How Managers Use the Balanced Scorecard to Support Strategy Implementation and Formulation Processes. Tékhne-Review of Applied Management Studies, (1), 2-15.

Gamal, A., \& Soemantri, A. I. (2017). The Effect of Balanced Scorecard on the Private College Performance (Case Study at the University of WR Supratman Surabaya). Archives of Business Research, 5(5).

Gmelch, W. H., \& Wolverton, M. (2002). An Investigation of Dean Leadership.

Hendricks, K., Menor, L., Wiedman, C., \& Richardson, S. (2004). The Balanced Scorecard: to Adopt or Not to Adopt? Ivey Business Journal Online, 11.

Horngren, C., S. Datar, And M. Rajan. (2012). Cost Accounting: A Managerial Emphasis. 14th Edition. Upper Saddle River, NJ: Prentice Hall.

Hu, B., Leopold-Wildburger, U., \& Strohhecker, J. (2017). Strategy Map Concepts in a Balanced Scorecard Cockpit Improve Performance. European Journal of Operational Research, 258(2), 664-676.

Huang, C. D., \& Hu, Q. (2007). Achieving IT-Business Strategic Alignment via Enterprise-Wide Implementation of Balanced Scorecards. Information Systems Management, 24(2), 173-184.

Jusoh, R., \& Parnell, J. A. (2008). Competitive Strategy and Performance Measurement in the Malaysian Context: An Exploratory Study. Management Decision, 46(1), 5-31.

Kaplan R.S. And Norton D.P. (1992). The Balanced Scorecard - Measures that Drive Performance. Harvard Business Review, 70.1: 71-79.

Kaplan R.S. And Norton D.P. (2004): Strategy Maps: Converting Intangible Assets into Tangible Outcomes. Harvard Business School Press, Boston, MA.

Kaplan, A. M., \& Haenlein, M. (2010). Users of the World, Unite! The Challenges and Opportunities of Social Media. Business Horizons, 53(1), 59-68.

Kaplan, R. And Norton, D. (2001), "Transforming the Balanced Scorecard from Performance Measurement to Strategic Management: Part I", Accounting Horizons, Vol. 15 No. 1, Pp. 87-104.

Kaplan, R. S., \& Norton, D. P. (1996a). Using the Balanced Scorecard as a Strategic Management System.

Kaplan, R. S., \& Norton, D. P. (1996b). Linking the Balanced Scorecard to Strategy. California Management Review, 39(1), 53-79.

Kaplan, R. S., \& Norton, D. P. (1999). The Balanced Scorecard for Public-Sector Organizations. Balanced Scorecard Report, 15(11), 1999.

Kaplan, R. S., \& Norton, D. P. (2000). Putting the Balanced Scorecard to Work. Focusing Your Organization on Strategy - with the Balanced Scorecard, 2, 2-18.

Kaplan, R. S., \& Norton, D. P. (2006a). Alignment: Using the Balanced Scorecard to Create Corporate Synergies (Vol. 1). Boston Massachusetts: Harvard Business School Press.

Kaplan, R. S., \& Norton, D. P. (2006b). How to Implement a New Strategy without Disrupting Your Organization. Harvard Business Review, 84(3), 100.

Karathanos, D., \& Karathanos, P. (2005). Applying the Balanced Scorecard to Education. Journal of Education for Business, 80(4), 222-230.

Khomba, J. K., Vermaak, F. N., \& Hanif, R. (2012). Relevance of the Balanced Scorecard Model in Africa: Shareholder-Centred or Stakeholder-Centred?. African Journal of Business Management, 6(17), 5773.

Kim, J., Suh, E., \& Hwang, H. (2003). A Model for Evaluating the Effectiveness of CRM Using the Balanced Scorecard. Journal of Interactive Marketing, 17(2), 5-19.

Lee, N. (2006). Measuring the Performance of Public Sector Organisations: A Case Study on Public Schools in Malaysia. Measuring Business Excellence, 10(4), 50-64.

Lubis, A., Torong, Z. B., \& Muda, I. (2016). The Urgency of Implementing Balanced Scorecard System on Local Government in North Sumatra-Indonesia. International Journal of Applied Business and Economic Research, 14(11), 7575-7590.

Lynch, R.L. And Cross, K.F. (1991), Measure Up - The Essential Guide to Measuring Business Performance, Mandarin, London

Maiga, A. S., \& Jacobs, F. A. (2003). Balanced Scorecard, Activity-Based Costing and Company Performance: An Empirical Analysis. Journal of Managerial Issues, 283-301.

Marr, B., \& Schiuma, G. (2003). Business performance measurement - past, present and future. Management decision, 41(8), 680-687. doi:10.1108/00251740310496198

Martello, M., Watson, J. G., \& Fischer, M. J. (2016). Implementing a Balanced Scorecard in a Not-For-Profit Organization. Journal of Business \& Economics Research (Online), 14(3), 61. 
Merriam, S. B. (1988). Case Study Research in Education: A Qualitative Approach. Jossey-Bass.

Miles, M. B., \& Huberman, A. M. (1994). Qualitative Data Analysis: An Expanded Sourcebook. Sage.

Modell, S. (2012). The Politics of the Balanced Scorecard. Journal of Accounting \& Organizational Change, 8(4), 475-489.

Moon, P., \& Fitzgerald, L. (1996). Delivering the Goods at TNT: The Role of the Performance Measurement System. Management Accounting Research, 7(4), 431-457.

Nambi Karuhanga, B., \& Werner, A. (2013). Challenges Impacting Performance Management Implementation in Public Universities: A Case of Uganda. African Journal of Economic and Management Studies, 4(2), 223243.

Neely, A., \& Bourne, M. (2000). Why Measurement Initiatives Fail. Measuring Business Excellence, 4(4), 3-7.

Neely, A., Adams, C., \& Kennerley, M. (2002). The Performance Prism. Financial Times, Prentice-Hall, London.

Neely, A., Gregory, M., \& Platts, K. (2005). Performance Measurement System Design: A Literature Review and Research Agenda. International Journal of Operations \& Production Management, 25(12), 1228-1263.

Nielsen, S., \& Nielsen, E. H. (2008). System Dynamics Modelling for a Balanced Scorecard: Computing The Influence of Skills, Customers, and Work in Process on The Return on Capital Employed. Management Research News, 31(3), 169-188.

Nørreklit, H. (2003). The Balanced Scorecard: What Is The Score? A Rhetorical Analysis of The Balanced Scorecard. Accounting, Organizations and Society, 28(6), 591-619.

Osewe, J. O., Gachunga, H., Senaji, T., \& Odhiambo, R. (2018). Relationship between Management Fashion Rationale for Balanced scorecard Adoption and Organizational Performance of State Corporations in Kenya. Journal of Developing Country Studies, 3(1), 1-15.

Othman, R. (2008). Enhancing the Effectiveness of the Balanced Scorecard with Scenario Planning. International Journal of Productivity and Performance Management, 57(3), 259-266.

Othman, R., Domil, A. K. A., Senik, Z. C., Abdullah, N. L., \& Hamzah, N. (2006). A Case Study of Balanced Scorecard Implementation in a Malaysian Company. Journal of Asia-Pacific Business, 7(2), 55-72.

Pandey, I. M. (2005). Balanced Scorecard: Myth and Reality. Vikalpa, 30(1), 51-66.

Papenhausen, C., \& Einstein, W. (2006). Implementing the Balanced Scorecard at a College of Business. Measuring Business Excellence, 10(3), 15-22.

Rigby, D., \& Bilodeau, B. (2011). Management tools \& trends 2011. London: Bain \& Company.

Sandhu, R., Baxter, J., \& Emsley, D. (2008). The Balanced Scorecard and its Possibilities: The Initial Experiences of a Singaporean Firm. Australian Accounting Review, 18(1), 16-24.

Sharma, A. (2009). Implementing Balance Scorecard for Performance Measurement. IUP Journal of Business Strategy, 6(1), 7.

Singh, R. K., \& Arora, S. S. (2018). The Adoption of Balanced Scorecard: An Exploration of its Antecedents and Consequences. Benchmarking: An International Journal, (Just-Accepted), 00-00.

Slavica, T., Ljubica, K., \& Jelena, J. (2017). The Modern Concept of Measuring Efficiency-Implementation and Attitudes of BSC. Tem Journal-Technology Education Management Informatics, 6(3), 525-533.

Tarigan, R. (2005). An Evaluation of the Relationship between Alignment of Strategic Priorities and Manufacturing Performance. International Journal of Management, 22(4), 586.

Taylor, J., \& Baines, C. (2012). Performance Management in UK Universities: Implementing the Balanced Scorecard. Journal of Higher Education Policy and Management, 34(2), 111-124.

Umashankar, V., \& Dutta, K. (2007). Balanced Scorecards in Managing Higher Education Institutions: An Indian Perspective. International Journal of Educational Management, 21(1), 54-67.

Vermaak, F. N., \& Cronje, C. J. (2001). The balanced scorecard as a potential instrument for supporting the planning and improvement of accounting education in South Africa. Meditari: Research Journal of the School of Accounting Sciences, 9(1), 301-312.

Walker, K. B., \& Ainsworth, P. L. (2007). Achieving Competitive Advantage in Departments of Accounting: Management Principles and the Balanced Scorecard. Academy of Accounting and Financial Studies Journal, 11(1), 65-82.

Witcher, B. J., \& Sum Chau, V. (2007). Balanced Scorecard and Hoshin Kanri: Dynamic Capabilities for Managing Strategic Fit. Management Decision, 45(3), 518-538.

Wong-On-Wing, B., Guo, L., Li, W., \& Yang, D. (2007). Reducing conflict in balanced scorecard evaluations. Accounting, Organizations and Society, 32(4-5), 363-377.

Yin, R. K. (1998). The Abridged Version of Case Study Research: Design and Method.

Yin, R.K. (2003), Case Study Research: Design and Methods, 3rd Ed., Sage Publications, New York, NY. 
Zangoueinezhad, A., \& Moshabaki, A. (2011). Measuring University Performance Using a Knowledge-Based Balanced Scorecard. International Journal of Productivity and Performance Management, 60(8), 824-843.

Zheng, C., Morrison, M., \& O'Neill, G. (2006). An Empirical Study of High Performance HRM Practices in Chinese Smes. The International Journal of Human Resource Management, 17(10), 1772-1803.

Zin, N. M., Sulaiman, S., Ramli, A., \& Nawawi, A. (2012). Balanced Scorecard Implementation Within a Malaysian Government-Linked Company. Asia-Pacific Management Accounting Journal, 7(1).

Zolfani, S. H., \& Ghadikolaei, A. S. (2013). Performance Evaluation of Private Universities Based on Balanced Scorecard: Empirical Study Based on Iran. Journal of Business Economics and Management, 14(4), 696714.

Appendix A: The Impact of UUM Strategic Plans on its Ranking Profile

\section{OSUNIVERSITY RANKINGS ASIA}

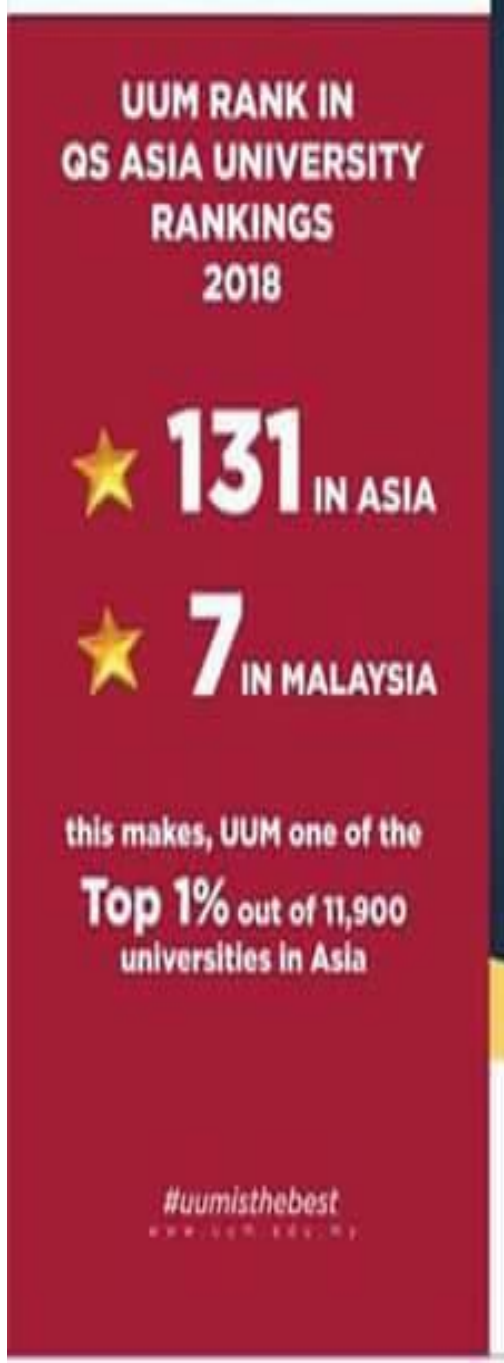

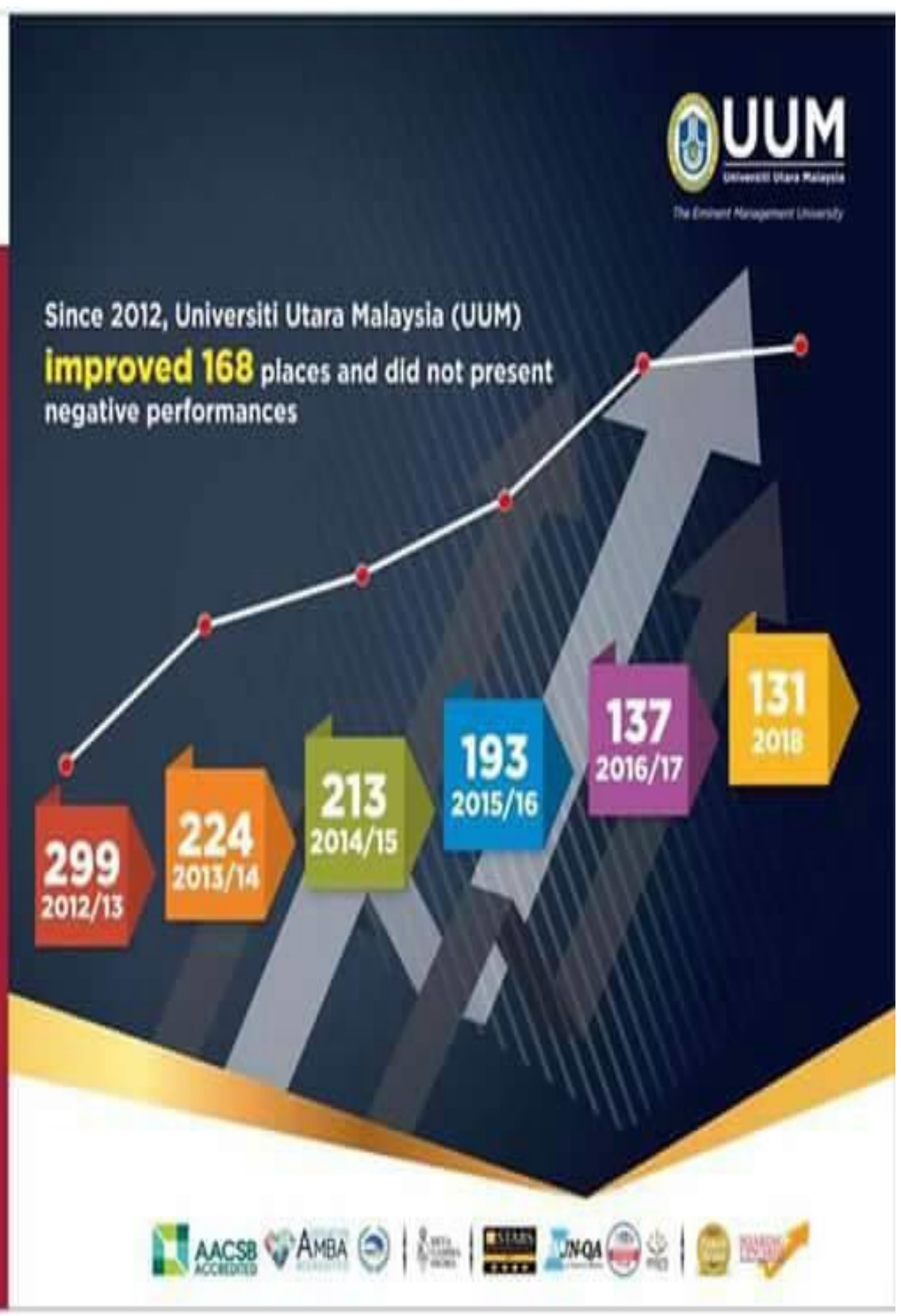
improved 168 places and did not present negative performances

Figure 1.UUM’s 2018 rank in QS Asia University Rankings 


\section{TOP 25 UNIVERSITIES in Southeast Asia 2018}

\section{Ûni Rank}

$1 \backsim$ National University of Singapore

$2 \square$ Nanyang Technological University

3 Universitas Gajah Mada

4 毫 Universiti Teknologi Mara

5 Mahidol University

$6 \quad$ Univesitas Indonesia

7 毫 University Putra Malaysia

8 毫 Universiti Kebangsaan Malaysia

9 铻 Universiti Malaya

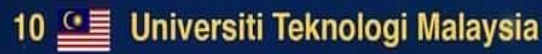

11 Easetsart University

12 Universitas Negeri Yogyakarta

13 Singapore Management University

14 E Chulalongkorn University

15 全 Universiti Sains Malaysia

16 毫 Universiti Utara Malaysia

17 Universitas Brawijaya

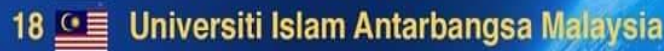

19 Prince of Songla University

20 Insitut Pertanian Bogor

21 Universitas Diponegoro

22 ․ Thammasat University

${ }^{23}$ Universitas Sebelas Maret

24 Chiang Mai University

25 Universitas Sumatera Utara

(0) seasialG

seasia

Figure 2. UUM's 2018 rankings among the top 25 universities in Southeast Asia

Appendix B: The Key Success Factors of UUM's Strategic Plan

Table 4.1 The Four (4) thrust

\begin{tabular}{ll}
\hline S/N & The Four thrust \\
\hline 1 & Enhancing Scholarship and Internationalization \\
\hline 2 & Developing Human Capital and Talent Management \\
\hline 3 & Focusing on the Holistic Development of students \\
\hline 4 & Generating/Creating Wealth \\
\hline
\end{tabular}


Six Key Result Areas (KRA)

Also, in order to facilitate the execution of this strategic plan, the university has outlined six (6) Key Result Areas (KRA) which is shown in table 4.2

Table 4.2 Six Key Result Areas (KRA)

\begin{tabular}{ll}
\hline S/N & 6 Key Result Areas (KRA) \\
\hline 1 & Research and high-impact innovations \\
\hline 2 & High impactful teaching and learning activities \\
\hline 3 & High performance students \\
\hline 4 & High performance human capital and institutions \\
\hline 5 & Sustainable wealth creation and Management \\
\hline 6 & Conducive infrastructure and learning environment \\
\hline
\end{tabular}

Table 4.3 7 Objectives

\begin{tabular}{cl}
\hline S/N & \multicolumn{1}{c}{ 7 OBJECTIVES } \\
\hline 1. & To provide cutting edge research consultation and publication \\
\hline 2. & To establish effective teaching and learning \\
\hline 3. & To produce highly capable talent and human capital \\
\hline 4. & To develop reputable academic programs \\
\hline 5. & To provide state of the art infrastructure \\
\hline 6. & To produce holistic, entrepreneurial and balanced student development \\
\hline 7. & To establish effective and efficient financial management \\
\hline
\end{tabular}

Table 4.4 12 Strategies

\begin{tabular}{cl}
\hline S/N & 12 STRATEGIES \\
\hline 1. & Enhance high impact research \\
\hline 2. & Enhance high impact consultation \\
\hline 3. & Enculturate high impact publication \\
\hline 4. & Strengthen flagship and executive education programmes \\
\hline 5. & Strengthen teaching and learning competencies \\
\hline 6. & Empower human capital and talent development \\
\hline 7. & Development of balanced students - entrepreneurship and global employability. \\
\hline 8. & Modernize infrastructure \\
\hline 9. & Optimize infrastructure cost \\
\hline 10. & Enhance financial sustainability \\
\hline 11. & Optimize research funding \\
\hline 12. & Enhance sustainable cost saving \\
\hline
\end{tabular}

Table 4.5 16 Key Performance Indicators (KPIs)

\begin{tabular}{|c|c|}
\hline $\mathrm{S} / \mathrm{N}$ & 16 Key Performance Indicators (KPIs) \\
\hline 1 & Research \\
\hline 2 & Consultation \\
\hline 3 & Publication \\
\hline 4 & Flagship program \\
\hline 5 & Teaching and learning competencies \\
\hline 6 & High performance staff \\
\hline 7 & Students with multi-competencies \\
\hline 8 & Student mobility \\
\hline 9 & Employability \\
\hline 10 & Education center \\
\hline 11 & Student accommodation facility \\
\hline
\end{tabular}




\begin{tabular}{ll}
\hline 12 & University infrastructure \\
\hline 13 & Sustainable income - Academic \\
\hline 14 & Sustainable income - Non-Academic \\
\hline 15 & Research funding \\
\hline 16 & Cost reduction \\
\hline
\end{tabular}

Appendix C: Interview Schedule

The Implementation of BSC and its Impact on Performance: Case of UUM

Time/Date: 3:35-4:10 21/12/16 (Wednesday) - First interview in IPQ

Time/Date: 11:30-11:45 17/01/17

- Second interview in TISSA

The objective of this research is to find out the implementation processes of BSC and its impact on performance in UUM (and to also access how the quality of services provided could be improved).

1. KPI implementation process from the 2010-till date (i.e. the processes involved in implementing BSC in UUM)

2. How you developed the planning process

3. Your role, responsibility and experience in the implementation process

4. The perspectives of the BSC adopted by UUM whether is exactly the same with the one proposed by Kaplan and Norton

5. The issues involved in the implementation of BSC

6. The impacts on performance

7. What is the critical success factors (CFS) i.e. what are the factors that contribute to the successful implementation of BSC e.g. Case evidence in Geomotion indicates that four critical factors are found to be the critical success factors in the successful implementation of BSC. These factors which consist of (1) top management commitment, (2) communication, (3) information technology, and (4) organizational culture.

8. How do you translate the university's aims and objectives into goals and measures? (I.e. objectives, measures, targets, initiatives).

9. What or how does the strategy map of the university looks like (please annotate with strategy map diagram)

10. How do you link performance measurement and the strategies you have put in place towards achieving the mission and vision of the university (strategy map).

11. The BSC is a "living document" that requires regular revision of objectives, measures, and initiative. How often do you do that?

12. In a business oriented organization the financial perspective is considered more important in contrast to the educational institution where customer perspective is regarded more. What are the measures put in place to ensure customer/stakeholder satisfaction?

13. Having said all these, where do you see UUM going in the future or does the BSC implementation indicate any positive impact on its performance towards improving the university institutional ranking?

\section{Copyrights}

Copyright for this article is retained by the author(s), with first publication rights granted to the journal.

This is an open-access article distributed under the terms and conditions of the Creative Commons Attribution license (http://creativecommons.org/licenses/by/4.0/) 